\title{
GENERAL INDEX.
}

The numerals in heavy type indicate that the species to which they refer is figured.

Acacia arabica, var. kraussiana, 116.

" spirocarpoides, 116.

Acari in N. Nigeria, 322, 328, 346.

acarta, Olfersia, 172 note.

accraensis, Culex, 247.

" Culicelsa, 247, 256, 261.

actinella, Tachardia, in Natal, 100 ; com-

pared with T. longisetosa, 103.

acuminata, Kirkia, 360.

Adansonia digitata, puparium of Glossina morsilans, at base of, 359 .

Aedides, 242, 243.

Aedinee, 241.

aegypti, Culex, 265.

aegypticus, Goniocotes, sp. n., 148.

aegyptium, Hyalomma, 197, 212, 230.

aethiopicus, Phacochoerus, lonse of, 145.

africana, Antonina, 100, 101.

" Atthegella, 129, 130, 135.

" Fiorinia, sp. n., 90.

" Lecaniodiaspis, sp. n., 100-102.

" Mansonia, 254.

"Stogomyia, 27.

africanum, Menopon, sp. n., 149, 160.

africanus, Ceroplastes, common in Egypt, 97.

” Linognathus, sp. n., 146.

" Mucidus, 246.

" Tabanus, 112, 279, 339, 346.

" Taeniorhynchus, 251.

Afrelia, 117.

aganippes, Leptopsylla, 271.

ager, Culex, 259 ; var. sinensis, 259.

" Taeniorhynchus, 256, 259.

24642
Agromyza salicifolii, sp. n., 79 ; bred from mines in willow leaves, Egypt, 80.

aitkeni, Anopheles, a true Stethomyia, 141. Akidoproctus maximus, 148.

"stenopygus, from spurwing goose, Sudan, 148; distinct from $A$. maximus, 149.

albicollis, Corvultur, lice on, 147, 149, 151.

albida, Tachardia, in Natal, 100.

albifasciatus, Ochlerotatus, 247.

albipalpus, Tabanus, 325, 327, 346.

albitarsis, Megaculex, 245.

alboannulatus, Culicelsa, 247.

albovirgatus, Culex, 259.

Algeria, Culicinae in, 248, 249, 251, 265.

alternans, Mucidus, 246.

ambigua, Grabhamia, 259.

Amblyomma nuttalli, in N. Nigeria, 320.

" variegatum, in Gambia, 197 ;

in $\mathrm{N}$. Nigeria, 319, 322, 325, 330.

anarmostus, Culex, 259, 260.

Anglo-Egyptian Sudan, two new spp. of Tabanus from, 173-177; Cimex rotundatus, in, 179-180; Anoplura and Mallophaga from, 145-152.

Angola, Culicinae in, 252, 259, 262.

annettii, Chrysoconops, 253.

" Taeniorhynchus, 253.

annulata, Reedomyia, 320.

"Theobaldia, 251.

annulifera, Mansonia, 253.

annulipes, Mansonia, 253.

annulioris, Culex, 259.

annulirostris, Culicelsa, 259.

Anopheles, new W. African spp. with notes on nomenclature, 141143. 
Anopheles aitkeni, appears to be a true Stethomyia, 141.

$" \quad$ argyrotarsis, type of Nyssorhynchus, 141.

" (Myzomyia) flavicosta, sp. n., 142-143.

" ludlowi, considered a var. of A. rossi, 143.

$" \quad$ rossi, type of Myzomyia, 141.

" umbrosa, distinct from $A$. funesta, 142.

" watsoni, sp.n., 143 ; occorrence at Minna, 330.

Anophelina, 241, note; spp. in N. Nigeria, $321,328,345$.

Anopheíinae, notes on nomenclature, 141 .

Anophelines, infected, where to find, 1 ; method of capture, 1 ; identification of species, 1-2 ; dissection of, 2-5 ; endoand ecto-parasites, 6 ; infection of, 6 ; problems concerning infection of, 7-8; properties of salivary secretion, 8; suggested lines of research, 8 ; " black spores" (Ross) in, 5; breeding in native domestic water-vessels, 133 ; Haplochilus grahami eats larvae of, 137 ; occurrences in Gambia, 201, 205, 217; larvae and pupae abundant in pools N. of Minna, 330 .

Anoplura, from African hosts, 145-147 ; instructions for collecting, 238-239.

Antelope, sable, in relation to tsetse, 43, 44, 45.

antennatum, Menopon, sp. n., 150-151.

anthropophaga, Cordylobia, 206.

Antonina africana, published inadrertently, 100, 101.

" (see Lecaniodiaspis).

Aonidia glandulosa, 103-104; in Egypt on Acacia arabica, 104.

Aponomma exornatum, in N. Nigeria, 320.

Aporoculex, included in Culex, 256.

" punctipes, synonym of Culex quasigelidus, 258.

aquilus, Culex, 264.

arabica, Acacia, 116.

" Mansonia, 249.

arabicus, Culex, 249.

Arachis hypogaea, 193.

Argasidae, instructions for collecting, 232 ; occurrence in N. Nigeria, 346.

Argas persicus, 232. argyrotarsis, Anopheles, 141.

arundinum, Cervicapra, lice on, 147.

Ashanti, Glossina taken in, 18, 34 ; Culex

and allied genera in, $245,246,248,259$, $263,265$.

asini, Baematopinus, 145.

Aspidiotus cydoniae, synonym of A. lataniae, $8 \mathbf{0}$.

" hederce, in German E. Africa, 85 ; on Magnolia and Datura $a l b a$, in Cairo, 86.

" lataniae, A. cydoniae synonym of, 87 ; on Antigonon octopus, in Uganda, 86.

" trilobitiformis, occurrence in German E. Africa on Oleander, 85.

Aspidoprocitus maximus, a pest in Bhodesia, 100 ; occurrence in German $\mathbf{E}$. Africa, 100.

Aswan (Egypt), Coccidae from, 102, 104.

Atthegella africana, in nutive watervessels at Lagos, 129, 130, 135.

Auchmeromyia luteola, occurrence in Gambia, 205, 206, 212.

Aulacaspis (see Diaspis).

aureosquamiger, Anopheles, 143.

aurites, Chrysoconops, 252.

, Taeniorhynchus, 252, 253.

austeni, Anopheles, 143.

azoriensis, Culex, 263.

Baboons, 206, 223.

baculus, Lipeurus, 149.

Bagana (N. Nigeria), Sleeping Sickness and Horse Trypanosomiasis at, 339.

Banksinella chrysothorax, synonym of $B$. luteolateralis, 245.

" luteolateralis, distribution and synonyms, 245 ; in $\mathbf{N}$. Nigeria, 317, 337.

" metallicus, referred to Taeniorhynchus, 352.

" punctocostalis, in Ashanti, 245.

" taeniarostris, may be a var. of luteolateralis, 245.

barbirostris, Myzorhynchus, 268.

Baro (N. Nigeria), importance of, 304, 327 ; mosquito breeding area near, 328 ; distribution of Glossina near, $329, \mathbf{3 3 0}$; recommendations with regard to, 355 ; biting flies and ticks at, 328 ; trypanosomiasis in, 328 . 
Bassa Province (N. Nigeria), Sleoping Sickness in, 339 ; Horse Sickness in, 340-345, 353 ; recommendations with regard to, 355 .

Bathurst (Gambia), residential quarters, Stegomyia fasciata and tsetse infest, 195.

beckii, Mytilaspis, synonym of M. citricola, 88.

Bed-bugs, in native houses, 212 ; instructions for collecting, 234 .

Beira (Mozambique), Glossina morsitans and $G$. brevipalpis near, 41 , and note.

Bembex capensis, preying on Holcoceria nobilis, 182.

" tricolor, preying on Tabanus secedens, 182.

biclavis, Chionaspis, mining habits of, 88 .

bicolor, Chrysops, sp. n., 162, 163.

" Culex, 266.

" Culicada, 256, 266.

bifoliata, Culex, 261.

biguttatus, Tabanus, 112.

" var. croceus, Tabanus, 321, 324, $325,328,330,346$.

Bintang Creek (Gambia), in regard to tsetse, 208-211.

Bironella, considered distinct from Anopheles, 141.

bisignata, Myzomyia, 268.

"Black spores" (Ross) in Anophelines, 5.

blanchardi, Parlatoria, male puparia of, 88, 89 ; possible variety of, 92.

Blood-sucking Arthropods, from Gambia, 214-218; from N. Nigeria, $345,346$.

9

Diptera, in Dowa District, Nyaraland, 111,112 ; in Ilesha District, S. Nigeria, 273-276.

Bornu Province (N. Nigeria), haunts of Glossina tachinoides in, 119-126.

bostocki, Culex, 264.

Boycia mimomyiaformis, belongs to Megaculex, 244, note; should probably be included in Ludlowia, 266.

Brachystegia pectinata, 117.

Breoding grounds of Phlebotomus, 48-52 ; destruction of, 55,56 .

brevicomis, Linognathus, 147. brevipalpis, Glossina, group characters, 9 ; male armature 10-12 ; male and female, description, 19-21; occurrences in Nyasaland, 19 ; erroneously referred to as fusca, 41 , note; colour conventions for, 298, and note.

British E. Africa, Glossina taken in, 31.

brucei, Trypanosoma, 353.

Buffalo, in relation to tsetse, 43, 44.

bullatifrons, Haematopota, 324-327.

cacti, Diaspis, on Opuntia in Egypt, 87.

Cairo, Coccidae from 85, 86, 97, 102.

calcitrans, Stomoxys, empty pupae of, in caves in Malta, 48 ; distribution, 197 , 207, 208, 319-321, 323, 324, 327, 333, 346.

caliginen, Glossina, 10-12, 14, 23-25.

caliginosus, Ochlerotatus, 250.

Calosoma sycophantx, preying on Gipsy Motb, 369.

Calvertina, considered distinct from Anopheles, 141.

calyptroides, Diaspis, in Egypt, 87.

camelarius, Tabanus, sp. n., 173-175.

camelina, Hippobossa, 170, 171, 346.

cana, Chrysops, sp. n., 166.

canis, Ctenocephalus, 321, 324.

Cape Colony, Culicidae from, 251, 263.

capensis, Bembex, 182.

Cape St. Mary (Gambia), residential quarters of Bathurst to be moved to, 195, 196 ; site for Sleeping Sickness camp at, 197, 224; area could be easily freed from tsetse, 198.

capitis, Pediculus, 145.

Casa Leoni (Malta), Phlebotomus in rabbit hutches at, 49,70 ; Phlebotomus perniciosus abundant at, 72 .

cassiae, Chionaspis, sp. n., 89, 90.

Cellia, included in Nyssorhynchus, 141 ; type sp. incorrectly cited, 141.

centurionis, Chrysops, sp. n., 164-166.

Ceroplastes africanus, common in Egypt, 97.

" Aoridensis, 95, 96.

$" \quad$ galeatus, sp. n.. 95.

" quadrilineatus, 95 ; prodnces crimson dye, 95. 
Ceroplastes rusci, on Crataegus, in Cairo, 97.

$" \quad$ ugandae, sp. n., 94 ; produces crimson dye, 95.

" vinsonioides, sp. n., 96.

Ceroplastodes gowdeyi, sp. n., 98, 99 ; associated with Lecanium nigrum, 100 ; presence of large paired glands in, 99, 100.

Cervicapra arundinum, Anoplura parasitic on, 147.

Ceylon, Coccidae on trees imported from, 86, 100.

Chagasia, considered distinct from Anopheles, 141.

Chalcidid, parasitic on Lecanium tenuivalvatum, 93 ; on Tachardia longisetosa, 103.

chamberlaini, Mimomyia, 244.

Chimaeropsylla potis, n. g. et n. sp. from Nyasa, 269-272.

Chionaspis biclavis, mining babits of, 88.

" cassiae, sp. n., 89, 90 ; on Cassia floribunda in Uganda, 90.

" dentilobis, in Uganda, 90.

" longispina; sp. n., 88 ; on Justicia alba in Egypt, 88 ; mining habits, 88.

n substriata. on Palm in Uganda, 90.

Chironomidae, 57 ; in Gambia, 218.

Chîronomus, larvae of, in domestic watervessels at Lagos, 129, 130, 134.

chloroventer; Culex, 264.

-choeropotamus, Potamochoerus, 145.

chorea, Dicranomyia, 263.

Chrysoconops, purely, an American genus, 251,252 ; African species described as, belong to Taeniorhynchus, 252, 253.

"nigra, 252.

" pseudoconopas, 253.

" taeniorhynchus, Culex titillans, wrongly determined as, 252.

Chrysops bicolor, 162-163,

$\quad \quad$ cana, sp. n., 166-168.
$\Rightarrow \quad$ centurionis, sp. n., 164-166.
$\Rightarrow \quad$ dimidiata, 165, 166.
$" \quad$ distinctipennis, in N. Nigeria, 333.
$" \quad$ longiqornis, in Gambia, 207.

Chrysops magnifica, sp. n., 161-163.

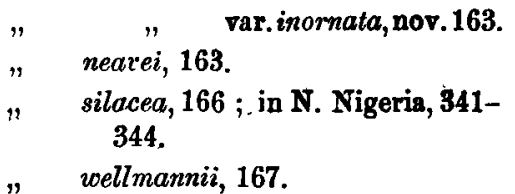

chrysothorax, Banksinella, 245.

Cimex rotundatus, in Anglo- Egyptian

Sudan, 179 ; distribution of, 180 ; common in Gambia, 212.

Cimicidae, in Gambia, 218 ; new, from British E. Africa, 363, 364.

cinerea, Culiciomyia nebulosa, var., 255.

cinereus, Culex, 254.

cinnamomi, Diaspis, 86 ; var. mangiferae, nov., 86 ; var. on imported mango trees in Egypt, 86.

cirnei, Rhynchocyon, 272.

citricola, Mytilaspis, 88.

claritibialis, Tabanus, 282.

clavipalpus, Rádioculex, 244, and note.

Climate, in Gambia, 191-193; in N. Nigeria, 308-314.

climax, Trichochetes, 147.

Clinocoridae, n, g. et. n. sp. of, $363,364$.

Clinocoris pilosellus, 364, note.

\#. . pipistrelli, 364 , note.

Coccidae, 85-104.

Collectors, hints for, -227-239 ; collecting and preserving fleas, 231, 232 ; collecting ticks, 232-234; collecting and preserving Cimicidae, 234; collocting Diptera, 234-237 ; tsetses, points on .which observations are wanted, 238 ; collecting Anoplura and Mallophaga, 238, 239; notes on bionomics wanted, 230 ; points to be mentioned on labels, $229,230$.

Colpocephalum flavescens, from vulture, 8. Nigeria, 149.

$"$ semicinctum, from $\mathrm{col}$. vultur albicollis, $\mathbf{8}$. Nigeria, 149.

" sjoestedti, from spotted rat, Uganda, 149.

Combretum microphyllum, 117.

commovens, Cylex, 246.

conchiformis, Inglisia, in Ugands, 98.

concolor, Culex, 261, 262.

condylodesmus, Culex; 259, 260, 268. 
Congo Free State, Glossina taken in, 18 ; Culicinae in, 245, 256, 259, 264, 265.

Conosia irrorata, African darker than Oriental, 262.

consimilis, Culex, 259.

, tigripes, var., 259.

Copaifera mopani, paparium of Glossina morsitans in hollow at base of trunk of, 358.

copemani, Tabanus, sp. n., 281, 282.

Coquillettidia, not separable from Taeniorhynchus, 252.

Cordylobia anthropophaga, 206.

Corethrinae, in Gambia, 218 ; sub-family or family, 241.

Corvultur albicollis, -Mallophaga parasitic on, 147, 149, 151.

costalis, Pyretophorus (see under Myzomyia).

" Myzomyia (see Myzomyia)

Cottonera (Malta), Phlebotomus found at, 48 ; breeding places at, 56.

cristatus, Chrysoconops, 253.

" Taeniorhynchus, 253.

croceus, Tabanus biguttatus, var. (see Tabanus).

crocodilinus, Tabanus, sp. n., 284.

Urustacea, in native water-vessels at Lagos, 129, 130, 134, 135 ; breeding in native yards, 136.

Ctenocephalus canis, abundant on dogs in N. Nigeria, 321,324 . felis, in Gambia, 200.

Culex, undetermined spp., 7 ; larvæ in in water-vessels at Lagos, 129 $131,132,133$; and allied genera, 241-268; legs of various species compared, 200 ; index of specific names of, 266-268; occurrences in $\mathbf{N}$. Nigeria, 319 , 320, 321, 328, 337, 345.

accraensis, 247, 261.

aegypti, 265.

ager, Oriental, 259.

" var., sinensis, 259.

albovirgatus, synonym of $C$. duttoni, 259.

anarmostus, synonym of $C$. duttoni 259 ; remarkable abnormality of $\mathrm{a}, \mathbf{2 6 0}$.

"annulioris, has been confused with C. duttoni, 259; distribution, 259.
Culex aquilus, synonym of $C$. invidiosus, 264.

arabicus, probably a homonym of

Mansonia arabica, 249.

azoriensis, included as a var. of

C. pipiens, 263.

bicolor, 266.

bifoliata, synònym of C.thalassius, 261.

bostocki, synonym of $C$. salisburiensis, 264.

chloroventer, synonym of $C$. invidiosus, 264.

cinereus, synongm of Culiciomyia nebulosa, 254.

commovens, a var. of Mucidus mucidus, 246.

concolor, compared with $C$. tigripes, 261, 262.

condylodesmus, probably only $C$. duttoni, 259, 260, 268.

consimilis, synonyms and distribution of, 259.

decens, in Gambia, 205 ; synonyms and distribution of, 263 ; iu $\mathbf{N}$. Nigeria, 319, 328, 345.

didieri, 266.

dissimilis, synonym of C. duttoni, $259,260$.

dorsalis, 247, 248, 249.

drymoecius, a var. of Taeniorhynchus fuscopennatus, 253.

duttoni, larve in native water vessels at Lagos, 129 ; number of vessels in which were larvae of, 130 ; seasonal variation of larvae of, 131 ; distribution of larvae, 132 ; sensitive to amount of chlorine in water, 132 ; possible carrier of Filaria diurna, 133 ; synonyms of, 259 ; distribution of, 260 ; mid leg of, 260 ; common at Oshogbo in October, 275 ; in N. Nigeria, 345 .

" euclastus, synonym of $C$. in. vidiosus, 264.

fatigans, included as a var. of $C$. pipiens, 262 ; in N. Nigeria, 262 , note, 345 .

freetowmensis, 254 ; specimens wrongly determined as, 255.

grahami, 263, 264 ; in N. Nigerı, $319,345$. 
Culex guiarti, 263; green colour not a soecific charaeter of, 263 ; in N. Nigeria, 319, 345.

hirsutipalpis, synonym of $C$. duttoni, 259.

insignis, 265.

invenustus, 252.

invidiosus, 241, 264 ; in N. Nigeria, $319,321,337,345$.

jamaicensis, is type of Grabhamia, 247, 256.

laurenti, 266.

leucacanthus, synonym of Ochlerotatus pulcritarsis, 249.

lividocostalis, synonym of $C$. decens, 263.

longefurcatus, 265.

maculicrura, 261.

maculiventris, 265.

masculus, synonym of $C$. decens, 263.

melanorhinus, 265.

microannulatus, 261.

minutus, synonym of $C$. decens, 263.

mundulus, 266, 268.

neavei, synonym of $C$. guiarti 263.

nigeriensis, 250.

nigrochaetae, 252, 254, 255, 256.

nigrocostalis, larvae in water vessels at Lagos, 129-131; larvae favourite food of $C$. tigripes, 133 ; synonym of $C$. decens, 263.

ornatothoracis, 263 ; thorax of, 264.

pallidocephala, included as a var. (if C. pipiens, 262.

pallidostriatus, synonym of Ochlerotatus ochraceus, 250.

pallidothoracis, synonym of $C$. pruina, 263.

pallipes, 265.

par, allied to or identical with C. consimilis, 266.

parascelos, synonym of Ochleratatus ochraceus, 250.

pettigrewi, synonym of C. theileri, $250,262$.

viliferus, 265.
Culex pipiens, Ochlerotatus compared with, 247 : varieties and dis. tribution, 248, 262, 263.

" pruina, 263 ; thorax of, 264.

" pruinosus, synonym of C. pruina, 263.

" pseudoannulioris, synonym of $C$. consimilis, 259.

" pseudocinereus, synonym of Culiciomyia nebulosa, 254.

pulcritarsis, 249.

" pullatus, synonym of C. grahami, 264.

pusillus, 265.

pygmaers, 266.

quasigelidus, synonyms of, 258 ; palpi of, 258 ; distribution of, 259 ; hind leg of, 260 ; thorax of, 264.

" quasiguiarti, synonym of $C$. zombaensis, 264 ; in $\mathbf{N}$. Nigeria, $321,328,345$.

" rima, distribution, 265 ; synonym of Melanoconion rimus, 265.

" rubinotus, 265.

rufinus, 265.

salisburiensis, synonym of $C$. bostocki, 264.

salsus, synonym of $C$. somaliensis, 261.

salus, sjnonym of C. somaliensis, 261.

sergenti, in Algeria, 265.

simpsoni, 263.

somaliensis, possibly a form of $C$. microannulatus, 261.

stoehri, incloded as a var. of C. pipiens, 263.

" taeniorhynchoides, synonym of $C$. quasigelidus, 258.

" thalassius, synonyms and distribution, 261.

"theileri, mid leg of, $260 ; C$. pettigrewi, synonym of, 262 ; distribution of, 262.

" tigripes, closely related to C. concolor, 261.

tigripes, var. consimilis, is a distinct species, 259.

tigripes, var. fusca, larvae in water vessels at Lagos, 129-131; 
wholly carnivorous, 133 ; includes darkest forms, 262 ; occurrence in $\mathrm{N}$. Nigeria, 321, 345.

Culex titillans, wrongly determined as Culicelsa taeniorhynchus, 252.

" transvaalensis, synonym of Ochlerotatus hirsutus, 249.

" univittatus, hind leg of, 260 ; synonyms and distribution, $250,262,345$.

" vigilax, 247, 250.

" viridis, synonym of C. guiarti, 263.

seltneri, 266.

" zombaensis, 264.

Culicada, synonym of Ochlerotatus, 246.

" bicolor, included in Culex, 256 , 266.

fuscopalpalis, synonym of Ochlerotatus cumminsii, 248.

lateralis, 250.

mediopunctata, var. of Ochlerotatus cumminsii, 248.

morsitans, included in Theobaldia, 251.

nemorosa, referred to Ochlerotatus, 248.

$"$

quasimodesta, seems to belong Culex, 256, 266.

Culicales, separate from Megalorbini, 241 ; table of genera, 242 ; table of females, 243 ; contiguous eyes in nearly all, 256.

Culicelsa, synonym of Ochlevotatus, 246, 247.

" accraensis (neotaeniorhynchus), is a Culex, $247,256,261$.

" alboannulatus, is a true Ochlerotatus, 247.

" annulirostris, included in Culex, 256.

neataeniorhynchus, same as Culex thalassius, 261.

taeniorhynchus, type of genus, 247 ; included in Ochlerotatus, 247, 249; Culex titillans, wrongly determined as, 252.

Culicidae, in water-vessels at Lagos, 129134 ; in Gambia, 217 ; classification of, 241; African forms often much darker than the Oriental, 262 ; six new spp. from Kamerun and Togo, 268; spp. from $S$. Nigeria, 274,275 ; in $N$. Nigeria, 231, 238, 345.

Culicides, 242, 243.

culicifacies, Myzomyia, 6.

Culicina, 241, note.

Culicinae, 241, 242.

Uulicines, where to find, 1 ; black spores in oocysts of C. fed on Proteosoma, 5 ; investigation of commoner house frequenting species should not be neglected, 6 ; can they transmit malaria, 7 ; five spp. of C. larvae eaten by Haplochilus grahami, $137 ; \mathbf{C}$. larvae and pupae abundant in pools north of Minna, 330.

Culiciomyia, only one variable African sp. of, 255 ; synonyms of, 254-256.

" dalzieli, synonym of Ochlero. tatus quasiunivittatus, 250, 255.

(?) insignis, sp. n. 37,38 ,

" referred to Culex, 265.

" nebulosa, synonyms and varieties of, 254-256 ; common in $W$. Africa, 256.

$" \quad$ nebulosa, var. cinerea, 255.

" " " freetoronensis, 255.

" " " fusca, 255.

" " pseudocinerea, 255 ; sp. described as Culex invenustus is probably, 256.

" uniformis, synonym of $C$. nebulosa, 255.

Culicoides, in N. Nigeria, 319, 324.

Culiseta absobrina, included in Theobaldia, 251.

cumminsii, Ochlerotatus, 248.

cuniculi, Spilopsyllus, 269.

Cyclops simillimus, present in watervessels at Lagos, 129, 130, 134; of importance in relation to transmission of Guinea Worm, 134 ; distribution of, 134 .

cydoniae, Aspidiotus, synonym of $A$. lataniae, 86.

Cyniphes molestus, synonym of Phlebotomus papatasii, 73. 
Cyprinodontidae, feeding on mosquito larvae, 137-139, 182.

Cypris, in water-vessels at Lagos, 129, 130 , 135 ; harbour Taenia, Trematodo larvae and $A$ canthocephalus, 135.

Dactylopius longispinus, on vine in Egypt, 100.

dalzieli, Culiciomyia, 250, 255.

Daphnia, in water-vessels at Lagos, 129 , 130,135 ; in relation to Taenia, Trematode larvae and Acanthocephalus, 135.

decens, Culex, 205̄, 263, 319, 328, 345.

decora, Haematopota, 197, 275, 321, 327, $331,334$.

decorella, Tachardia, new to Africa, 85, 100 ; compared with $T$. longisetosa, 103. defassa, Cobus, Hippobosca on, 170, 171.

Delagoa Bay, Culicinae in, 246, 250, 261.

Dendromyinae, 241.

dentatus, Ochlerotatus, 248.

dentilobis, Chionaspis, 90.

Dermatophilus penetrans, in N. Nigeria, 325.

Diaspinae, 86, 87, 90 .

Diaspis cacti, on Opuntia in Egypt, 87.

" calyptroides, 87.

" (Aulacaspis) cinnamomi, var. mangiferae, nov., 86 ; in Egypt on imported mango trees, 86 .

" cinnamomi, 86.

"regularis, sp. n., 86-87.

Dicranomyia chorea, 263.

didieri, Culex, 266.

digitata, Adansonia, 359.

dimidiata, Chrysops, 165, 166.

Diptera, photography of, 153-160 ; instructions for collectiog, 234-237 ; occurring in $N$. Nigeria, 321, 328, 345346 ; pupae among exposed roots of trees in $\mathbf{S . ~ R h o d e s i a , ~ 3 5 7 , ~} 359$.

dissimilis, Culex, 259, 260.

distinctipennis, Chrysops, 333.

ditaeniatus, Tabanus, 111, 200, 207, 321, $324,346$.

diurna, Filaria, in S. Nigeria, 132 ; possibly carried by Culex duttoni, 133.

Dogs, piroplasmosis of, 323-354 ; trypanocomiasis of, 344 . dorsalis, Culex, 247-249.

dorsalis, Grabhamia, 248.

dorsalis, Ochlerotatus, 248, 249.

Dowa district (Nyasa), habits of bloodsucking flies in, 111-112.

draperi, Sphaerococcus, synoujm of $S$. marlatti, 104.

Drosophila, in water-vessels at Lagos, 129 , $130,134$.

drymoecius, Culex, 253.

dukei, Olfersia, sp. n., 171, 172.

durandi, Enyaliopsis, 180.

durbanensis, Grabhamia, 250.

durbanensis, Ochleratatus, 250.

duttoni, Culex (see Culex).

Ebute Metta (S. Nigeria), Mosquito larvae in water-vessels at, 129-136; otber larvae and Crustacea, 134, 135 ; analysis of water containing larvae of Culex duttoni at, 132.

Eggs, of Mosquitos, 7 ; of Phlebotomus, $48,50,65,67$; of Phlebotomus papatasii, 75 ; of Pseudoeripopsylla, 106 ; of Mallopbaga, 239.

Egg parasites of Gipsy Motb and Browntail Moth, 369.

Egypt, Coccidae from, 85-88, 91, 92, 97, $100,102,103-104$.

eknomicus, Eoctenes, 152.

elongatum, Lecanium, on Albizzia in Ugands, 92 ; antenna and spines of, 92.

Entebbe (Uganda), new mosquito from, 38, Coccidae from, 86-88, 90, 92-95, $97,98,103$.

Enyalopsis durandi, injurious to man, 180.

" petersi, emits a yellow fluid when handled, 180.

Eoctenes elenomicus, 152.

Ephemeridae, occurrence in native watervessels in S. Nigeria, 129, 130, 134.

Epialurgi, 241.

Eretmapodites, contiguous ejes not found in, 256.

Essau (Gambia), swarms with Glossina palpalis, 213; removal of town recommended, 213, 224. 
Etorleptiomyia probably a synonym of Mansonia, 253.

" mediolineata, 253, 254.

euclastus, Cullex, 264.

Eugenia guineensis, 117.

Erulecanium (see Lecanium).

Eumelanomyia inconspicuosa, wrongly determined as Culex freetownensis, 255.

exornatum, Aponomma, 320.

falcatus, Rhipicephalus, 330.

fasciata, Stegomyia (see under Stegomyia).

fasciatus, Tabanus, 202, 321, 324, 346.

fatigans, Culex, 262, and note, 345.

felis, Ctenocephalus, 200.

Ficus, paparium of Glossina morsitans between roots of, $\mathbf{3 5 5}$.

Filaria diurna, occurrence in S. Nigeria, 132 ; possibly carried by Culex duttoni, 133.

Fiorinia africana, sp. . ., 90.

Fish and mosquito larvae, 137-139, 18 ?.

Flagellata, found in Anophelines, 6.

Alavescens, Colpocephalum, 149.

Aavicosta, Anopheles, sp. n., 142.

Flea, new, occurring on Rhynchocyon cirnei, 272.

Floriana (Malta), Phlebotomus breeding at, 51 ; Phlebotomus minutus taken at, $70 ; P$. perniciosus abundant at, 71.

floridensis, Ceroplastes, 95, 96.

Fly disease (see Trypanosomiasis of Cattlo).

Forcipomyia regulus, 57.

forficula, Linognathus, sp. n. 147.

freetownensis, Culex, 254, 255.

" Culiciomyia nebulosu, var., 255.

fulvus, Chrysoconops, 252.

Fundulus taeniopygus, preys on mosquito larvae, 182.

funesta, Anophele8, 142.

" Mysomyia, 6, 320, 321, 337.

fusca, Culex tigripes, var., 129-131, 133, $262,321,345$.

'" Culiciomyia nebulosa, var., 255.

" Glossina (

fuscipes, Glossina (see under Glossina).

fuscopalpalis, Culicada, 248.

fuscopennatus, Chrysoconops, 253. fuscopennatus, Taeniorhynchus, 253.

fuscum, Protomelanoconion, 244, 245, 264.

fuscus, Nirmus, 147.

" Pectinopalpus, 129-132, 244, 245, 255.

galeatus, Ceroplastes, sp. n. 95.

gambensis, Lipeurus, 149.

" Plectropterus, lice on, 148, 149, 151.

Gambia (British W. Africa), research in, 187-239 ; insect-borne diseases in, 188 ; geography and vegetation of, 188-191; climate and rainfall, 191-193 ; tribes inhabiting the Colony and Protectorate, 193-195 ; blood-sucking Artbropods from, 214-218; native names of blood-sucking insects and other Arthropods, 219 ; bionomics of Glossina in, 220-223 ; remedial measures and recommendations, 223-226 ; Culex and allied genera in, 258, 259, 261, 264.

" River, description of, 189-190 ; islands in, swarming with tsatses, 190 ; possibility of disease being carried from or into Senegal along, 195 ; Glossina palpalis haunts on banks of, 201-204 ; clearing spaces at wharres on, 225.

gambiense, Trypanosoma (see nnder Trypanosoma).

Game, in relation to tsetses, 43-46, 113$118,223$.

Garara, River (N. Nigeria), Glossina and mosquitos but no Tabanidae found near, 335-337; Sleeping Sickness not found in villages on, 352 .

gelida, var. sinensis, Leucomyia, 259.

German E. Africa, Coccidae from 85, 98, 100 ; new Chrysops from, 162 ; Glossina brevipalpis transmitting cattle-disease in; 181, 182; Culex and allied genera in, $251,262$.

gigas, Goniocotes, 148.

Girardinus poeciloides, preys on mosquito larvae, 182.

glandulosa, A onidia, sp. n., 103, 104.

Glossina, scheme of classifieation, 9,10 ; general characters of male armature, 10-12 ; methods of preparing male genitalia for microscopical. examination, 13, 14; - nynopsis of spp., 14, 
15 ; description of spp., 1536 ; game in relation to, $43-46$, 113; disappearance from Transvaal of, 115 ; can exist without game, 40, 117 ; colour of clothing attracting or repelling, 210,211 ; instructions for collecting, points on which observations are wanted, 238 ; colour conventions for, 297-299 ; distribution in N. Nigeria, 347-351 ; information desired concerning, 356 .

Glossina brevipalpis, gronp characters of, 9,14 ; male armature of, 10 12 ; male and female, description, 19-21 ; in Mozambique, 40-42; erroneously referred to as fusca, 41 , note; probable vector of cattle trypanosomiasis, 181.

caliginea, group characters of, 10 , 14 ; male armature of, 28-25.

fusca, group characters of, 9, and note; male armature of, 15-17; purely western, 41, note; not found in Gambia, 212 ; colour conventions for group of, 297-299; distribution in N. Nigeria, 347, and note, 350 .

fucipes, group characters of, 10 , 15 ; deecription of male, 26 , 27.

grossa, 9, and note, 17.

ongipalpis, group characters of, 10 , 15 ; male armature, 29 , 30 ; compared with $G$. pallidipes, 31 ; occurrence in $\mathrm{N}$. Nigeria, 328, 329, 336, 337, $341,344,346,347,349$.

"longipennis, group characters of, 9 , 14; male armature of, 21, 22.

" maculata, female only known of, 9 ; group cinaracters of, 14 ; distinct from palpalis, 22 .

" medicorum, male armature of, $107,109,110$.

morsitans, group characters of, 10,15 ; male armature of, 32 , 33 ; dark and light varieties of, 35 ; in Mozambique, 40 42 ; habits in Nyasa, 43-46, 112 ; extension of area of, 112 ; in relation to human trypanosomiasis, 112 ; in relation to cattle trypanosomiasis, 181 , note; occurrences in
Gambia, 199-201, 206, 207, $212,213,217$; bionomics of, 222,223 ; predilection for baboons, 206, 207, 223 ; preliminary stages of, 291-295; preserving and feeding captive, 292 ; breeding habits, 292, 293 ; larra of, 293, 294 ; puparium of, 294,295 ; duration of pupal stage of, 295 ; colour conventions for group of, 297,299 ; breeding haunts of, 357-361.

Glossina nigrofusca, group characters of, 9 , and note, 14 ; description of male and female of, 17-19.

, pallicera, group characters, 10, 15 ; male armature of, 27-29.

" pallidipes, group characters, 10 , 15 ; male armature, $30-32$; compared with longipalpis, 31 ; in Mozambique, 40-42; colour conrentions for, 297.

palpalis, group cbaracters of, 10,14 ; male armature of, 28 , 23 ; male from Rhodesia possibly distinct from, 107 ; distribution in Gambia, 197199, 200, 203-213, 216; hunted by a spider, 210 ; bionomics of, $220-222$; common in Ilesha district, $\mathrm{S}$. Nigeria, 276 ; colour conventions for group of, 297-299 ; distribution in N. Nigeria, 317-323, 326, 328, 331-345, 347, 349-353, 355.

" palpalis var. wellmani, 23.

" submorsitans, distinct from morsitans, 9; group characters, 10,15 ; male armature, 34, 35 ; compared with morsitans, 33,36 ; two varieties of, 33 , occurrences in Ashanti, 34 ; distribution in N. Nigeria, $320-322,324,326,328-330$, $338,339,346,349,350$.

tabaniformis, relationship, 9 and note; male armature, 108.

tachinoides, alliances and distinctions, 9 ; group characters, 10 , 15 ; male armature, 25 ; haunts in N. Nigeria, 119-126; var. of $G$. palpalis compared with, 202, 203, 204, note ; colour conventions for, 297299 ; distribution in N. Nigeria, $317-322,326,328,329$, 332$339,343,344,347,349-351$.

Gold Coast, Glossina tabaniformis in, 109 ; outbreal of Yellow Fever in, 127 ; 
Crustacea found in water-vessels in, 134, 135 ; Culex and alliod genera in, 246, 263, 264.

Goniocotes aegypticus, sp.n., from blue pigeon, Sudan, 148.

" gigas, from guines-fow], Budan, 148.

" major, compared with aegypticus, 148.

" procerus, compared with aegypticus, 148.

gowdeyi, Ceroplastodes, gen. et sp. n., associated with Lecanium nigrum, 92, 100 ; described, 98-100; presence of large paired glands in, 99, 100.

Grabhamia, synonym of Culex, 247.

" ambigua, 259.

1) dorsalis, 248.

" durbanensis, 250.

" jamaicensis, 256.

" maculosa, an extreme form of Ochlerotatus nemorosus, 248. ocellata, 250.

" pulcripalpis, probably synonym of Culex dorsalis, 248 , 249.

" pulcritarsis, 249.

" subtilis, pale var. of Culex dorsalis, 248.

" taeniarostris, 259.

" wilcocksii, pale var. of Culex dorsalis, 248.

gracilis, Haematopota, 324.

"Palacopsylla, 269.

grahami, Culex, 263, 264, 319, 345.

" Baplochilus, preys on mosquito larvae, 137-139; description of, 137, note, 189.

" Mucidus, 246.

Grassia, type Anopheles rossi, 141.

gratus, Tabanus, 175, 321, 330, 334, 346.

grossa, Glossina, 9 and note, 17.

griarti, Culex, 263, 319, 345.

guineensis, Eugenia, 117.

Haliaëtus vocifer, Olfersia on, 172.

Haplochilus grahami, preys on mosquito larvae, 137 ; description of, 137, note. 189.

" pumilus, preys on mosquito larve, 182.
Haplochilus senegalensis, 137, note.

Haemaphysalis leachi, occurring on dogs in Gambia, 212 ; on dogs in $\mathrm{N}$. Nigeria, 324 ; biting man, 326.

Haematopinus asini, from horse, Sudan, 145.

peristictus, sp. n., from wild pigs, Nyasa, 145-146. suis, compared with $\boldsymbol{H}$. peristictus, 145.

Haematopota bullatifrons, in N. Nigeria, 324-327.

" decora, in Gambia, 197 ; common in Oshogbo, $\mathbf{S}$. Nigeria, 275; does not bite man if animals present, 275 ; in $N$. Nigeria, 321, 327, 331, 333, 334.

" gracilis, in N. Nigeria, 324.

" lacessens, in N. Nigeria, 321, 324-326.

mactans, method of biting, 111.

pallidipennis, in $\mathbf{N}$. Nigeria, 321, 320-334.

pertinens, habitat and habits, 111.

puniens, in N. Nigeria, 326.

tenuicrus, in N. Nigeria, 321.

vittata, habitat and habits, 111.

hederae, Aspidiotus, in German E. Africa, 85 ; at Cairo on Magnolia and Datura alba, 86.

Helea (Forcipomyia) regulus, larval skin remains attached to pupa of, 57 .

Hemiptera, 238.

Heptaphlebomyia, included in Culex, 256.

montforti, synonym of Culex univittatus, 262.

" simplex, 우 synonym of Culex univittatus, 262 ; $\delta$ of $C$. decens, 263.

Heptaphlebomyinae, 242.

Haemasson minutus, 73.

hildegardeae, Taphozous, 364.

Hippobosca camelina, compared with $H$. hirsuta, 170; in N. Nigeria, 346.

hirsuta, sp. n., on Kobus defassa, Uganda, 169. 
llippobosca hirsuta, var. neavei, nov., on Kobus defassa, N.E. Rhodesia, 171.

, maculata, compared with $H$. hirsuta, 169, 170 ; in $\mathbf{N}$. Nigeria, 319, 321, 322, 324, $325,330,346$.

Hippoboscidae, not recorded from Gambia, 215 ; in Oshogbo, S. Nigeria, 275 ; in N. Nigeria, $322,346$.

Hippocentrum versicolor, in Oshogbo, $\mathbf{S}$. Nigeria, 275 ; in $\mathbf{N}$. Nigeria, 319, 320, 324, 325, 327, $330,346$.

hirsuta, Hippobosca, 169. " var. neavei, Hippobosca, 171.

hirsutipalpis,. Culex, 259, 260.

hirsutus, Ochlerotatus, 249.

hispida, Hispidimyia, 244, 245. " Ludlowia, 245.

Hispidimyia hispida, little different frum Ludlowia chamberlaini, 244, 245.

Holcoceria nobilis, prejed upon by Bembex, 18 ?.

Horse Sickness, enormous increase in Ilesha and Oshogbo districts of, 276 ; in $\mathbf{N}$. Nigeria, $319,320,323,324,326$, $330,332,334,336-339,341-345,353-$ 354 ; segregation camps for, 320,323 , 355 ; investigation required into forms of, 356.

Hyaliamma aegyptium, in Gambia, 197, 212 ; in N. Nigeria, 330.

Hydrachnidae, larvae found in Anophelines, 6.

Hymenoptera, parasites of Gipsy Moth and Brown-tail Moth, 369, 370.

hypogaea, Arachis, 193.

Ibo (Port. Nyasa), Glossina morsitans. near, 39, 40.

Icerya longisetosa, at Lake Nyasa, 100 ; on Acacia in German E. Africa, 100.

Ilesha district (S. Nigeria), blood-sucking flies of, 273-276; Mallophaga from, 147.

immaculata, Anopheles, 141.

inconspicuosa, Eumelanomyia, $25 \overline{.}$.

Inglisia conchiformis, in Uganda, 98.

Insecticides, kerosene for, 104, 355.

insignis, Culex, 265.

" Culiciomyia, $\mathbf{3 7}$.

intertropica, Olfersia, 172, and note.

invenustus, Culex, 256. invidiosus, Culex, 241, 264, 321, 337, 345.

Inyamandzi river (Mozambique), Glossina morsitans near, 41.

Inyambane district, disappearance of tsetse from, 42.

irrorata, Conosia, 262.

irroratus, Tabanus, 286.

Ixodidae, in N. Nigeria, 322, 328, 346.

Irodoidea, in Gambia, 218.

Izon (N. Nigeria), tsetses swarm at important ford near, 334.

jacksoni, Pulvinaria, in Uganda and W. Africa, 93 ; food plants, 93.

jamaicensis, Culex, 247, 256.

" Grabhamia, 256.

Kala-azar, Cimex rotundatus in relation to, 179 ; case in Sudan of, 180.

Katagum R. (N. Nigeria), Glossina submorsitans from, 34; Sleeping Sickness reported from, 352.

Kateri (N. Nigeria), Sleoping Bickness prevalent in, $330-333$; blood-8ncking flies at, 331-333; removal recommended, 332, 355.

Kerewan (Gambia), tsetse tronblesome at, 198 ; swarms of Glossina palpalis a mile from, 198 ; elephantiasis prevalent in, 199 ; clearing to be done at, 225.

Kerosene, emulsion for destroying Coccidae, 104 ;" use in pools for mosquito larvae, 355.

Khartoum, Cocidae from, 97.

Kingia, 268.

kingii, Mimeteculex, 250.

loingsteyi, Tabanus, 320.

Kirkia acuminata, puparia of Glossina morsitans at base of, 360 .

Kobus defassa, Hippoboscidae on, 170 , 171.

Kurimis, description of, 307 ; distribution of, $307,323,330-333,336,338,340$ 344 ; Glossina palpalis generally found in, 337 ; villages should be moved from, 344; lest camps should be mored further from, 355 .

lacessens, Hacmatopqta, 321, 324-326.

Lagos, Anopbelines occurring at, 6 ; examination of native water receptacles at, 127-136, analysis of water at, 132 ; mosquito larvae at, 129-136. 
Lake Chad, of great intereat in connection with Glossina, 305; system of, 306 ; area free from $G$..palpalis, 353 .

Ldke Nyassa, Coccidae from, 100.

Iake: Salisbury (Ugands), Pulvinaria jacksoni found on Cotton near, 93.

Lasioconops, incladed in Culex, 256.

$$
\text { -quasigelidus, } 258 .
$$

poicalipes, synonym of Culex

Lataniae, Aspidiotus, 86.

bateralis, Culicada, 250.

" Ochlerotatus, 250.

latipes, Tabanus, 318, 321, 328, 346.

laurenti, Culex, 266.

laverani, Tabanus, 205, 346.

Laverania, type, Anopheles argyrotarsis, 141.

leachi, Haemaphysalis, 212, 324, 326.

Lecaniodiaspis africana, sp. n., on Acacia arabica in Egypt, 100102.

" mimosae, 102.

" prospodidis, 102.

Lecanium elongatum, ( $=$ L. longulum), on Albizzia in Uganda, 92.

longulum, 92.

,

(Saissetia) nigrum, on Ficus in Uganda, 92 ; associated with Ceroplastodes gowdeyi, 100.

9 persicae, 93.

)

tenuivalcatum, on Citronella grass. in Uganda, 92 ; parasitised by a Chálcidid, 93.

" (Eulecanium) tremae,in Uganda, 23.

Lepidoptera, pupae in hollow of a Baobab, 359 ; parasites of Gipsy Moth and Brown-tail Moth, 365-371 ; controlling agencies for, $367,368,371$, and note.

Leptopsylla aganippes, 271.

" musculi, 269, 270.

leqpacanthus, Culex, 249.

leucarthrius Ochlerotatus, 251.

Leucomyia, included in Culex, 247, 256.

" gelida, var. sinensis, 259.

, quasigelida, 258.

" scapularis, referred to Ochlerotatus, 247.

" sinensis, var. of Culex ager, 259.

leucostomus', 'Tabanís, 176; 177 .
Liberia, Glossina mediconum from, 110.

Light, deterrent for Phlebotomus, 54"; artificial light attraets, 54 .

Limatinae, 241.

lineatopennis, Taeniorhynchus, 245.

Linognathus africamus, sp. n., from shoip, S. Nigeria, 146.

" brevicomis, 147.

" forficula, sp. n., from reedbuck, Nyasa, 147.

" tibialis, 147.

" vituli, from calf, Nyasa, 146.

Lipeurus baculus, from blue pigeon, Sudan, 149.

" gambensis, from spurwing goose, Sưdén, 149.

lividocostalis, Cutex, 263.

Lokoja (N. Nigeria), importance of; 304 , 318-320 ; Myzomyia costalis prevalent in, 319 ; ticks troublesome in, 319: mosquito larvae near, 319 ; trypanosomiasis in, 320,353 ; recommendations with regard to, 355 .

longefurcatus, Culex, 265.

longicornis, Chrysops, 207.

longifolia, Rhus, 117.

longipalpis, Glossina (see under Glossina).

" Stegomyia, 268.

longipennis, Glossina (see under Glossina). longisetosa, Icerya, 100.

" Tachardia, sp. n., 102, 103.

longispina, Chionaspis sp. n., 88.

longispinus, Dactylopius, 100.

longisquamosus, Ochlerotatus, 249.

longulum, Lecanium (see L, elongatum).

lowisii, Reedomyia, 250.

Loxaspis mirandus, g. et sp. n., from British E. Africa, 363, 364.

Lualowia, essential characters and table of spp. of, 244.

" hispida, 245.

" mimomyiaformis, in N. Nigeria, 337.

" pincerna, 245.

" plumosa, 245.

Lujenda River (Nyasa), tsetse-flies plentiful near, 39, $40,44,45$; tsetse absent west of, 118.

buridum, Trinoton, 151.

luteola, Auchmeromyia, 205, 206, 212. 
luteolateralis, Banksinella, 245, 317, 337.

Lutzia, included in Culex, 256 .

Lyperosia minuta, in Gambia, 197, 207.

MacCarthy Id. (Gambia), 189, 204, 205 ; not suitable as a site for Sleeping Sickness Camp, 224 ; clearing to be done at, 225.

mactans, Haematopota, habitat and method of biting, 111 .

maculata, Glossina (see under Glossina).

" Hippobosca (see ander Hippobosca).

maculatissimus, Tabanus, 286.

maculicrura, Culex, 261.

maculipalpis, Anopheles, 143.

maculipes, Taeniorhynchus tenax, var, 258.

maculiventris, Culex, 265.

maculosa, Grabhamia, 248.

Madagascar, Culex in, 259, 262.

madagascariensis, Pseudoheptophlebomyia, 258.

Maganjada Costa (Mozambique), Glossina spp. in district of, 41.

magnifica, Chrysops, 161-163.

" var. inornata, Chrysops, 163.

magrettii, Pangonia, 176.

Maillotia pilifera, 265.

major, Goniocotes, 148.

" Mansonia, 254.

Malaria, common in Gambia, 188 ; common but diminishing in N. Nigeria, 351 .

Mallophaga, from African hosts, 145-147 ; instructions for collecting, 239.

Malta, Phlebotomus perniciosus almost as abundant as $P$. papatasii in, 47 ; larrae in catacombs near centre of, 48 ; other investigators in, 49 ; means for destruction of Phlebotomus in, 53-56;P. perniciosus, widely distributed in, 71.

mangiferae, Diaspis cinnamomi, var., 86.

Mansonia, synonym of Taeniorhynchus, 252 .

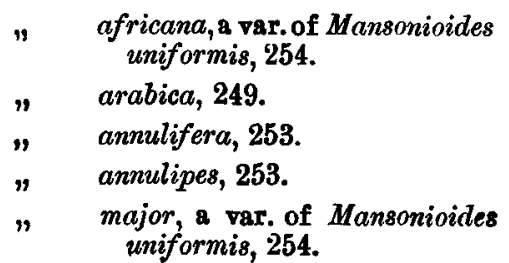

Mansonia nigerrima, a var. of Man sonioides uniformis, 254

nigra, 254.

" uniformis (see Mansonioides)

Mansonioides, characters of genus and table of spp., 253.

" mediolineata, 254.

" nigra, 254.

" uniformis, varieties and synonyms of, 254 ; structure of palpi, 254: distribution, 254, 275: affected with immature parasitic mito, 275 ; in $\mathrm{N}$. Nigeria, 319,321 , $324,328,330,336,337$, 345.

marlatti, Phoenicoccus, 104.

"Sphaerococcus, 104.

masculus, Culex, 263.

Mashonaland, Culicinae in, 245, 256.

maximus, Akidoproctus, 148.

"Aspidoproctus, 100.

medicorum, Glossina, 107, 109.

mediolineata, Etorleptiomyia, 253, 254.

" Mansonioides, 254.

mediopunctata, Culicada, 248.

Megaculex, subgenus of Ludlowia, 244, note.

" albitarsis, synonym of Ludlowia plumosa, 245.

Megalorhini, 241.

Megalorhinina, 241, note.

Megarhininae, 241.

Melanoconion, included in Culex, 256.

$$
\text { "rimus, } 265 .
$$

melanorhinus, Culex, 265.

Menopon africanum, sp. n., from spurwing goose, Sudan, 149.

" antennatum, sp. n., from guinea fowl, Sudan, 150.

" mesoleucum, from owl and atarling, Sudan, 149, 151.

nigrum, sp. n., from Corvultur albicollis, 151.

pallidum, from chicken, \&. Nigeria, 149.

picae, 151.

" spinosum, from starling, Sudan, 149.

mesolencum, Menopon, 149, 151. 
metallicus, Banksinella, 252.

" Taeniorhynchus, 252.

Metanototricha, 241; contiguous ejes in most of the, 256.

Metanototrichina, 241, note.

microannulatus, Culex, 261.

Micro-organisms found in Anophelines, 6.

Mimeteculex, synonym of Ochlerotatus, $247,248,250$.

" kingii, s5nonym of Ochlerotatus ochraceus, 250.

Mimomyia (?) chamberlani, Ludlowia, founded on, 244.

mimomyiaformis, Boycia, 244, note, 266.

$$
\text { " Luallowia, } 337 .
$$

mimosae, Lecaniodiaspis, 102.

Minna (N. Nigeria), blood-sucking flies and ticks obtained at, 330.

minor, Palaeopsylla, 269.

minuta, Lyperosia, 197, 207.

minutus, Culex, 263.

" Haemasson, 73.

"Phlebotomus (see under Phlebotomus).

mirandus, Loxaspis, sp. n., 363, 364.

mitrata, Numida, 148, 150.

mobola, Parinarium, 358.

molestus, Cyniphes, 73.

mopani, Copaifera, 358.

Mopea (Zambesi), cattle trypanosomiasis in 1908-9 at, 41 .

mordax, Tabanus, sp. n., 175.

morsitans, Culicada, 251.

" Glossina (see under Glossina).

Mosquitos, infected with malaria, 1-8; where to find, 1 ; method of capture, 1 ; identification of species, 1,2 ; disrection of, 2-5; gland examination, 3-4; staining of sporozoits, 4 ; dissection of mid-gat, 4-5; staining of zygotes, 5 ; endo- and ecto-parasites of, 6 ; problems concerning infection of, 7,8 ; properties of the salivary secretion of, 8 ; suggested lines of research, 8 ; larvae in water-vessels at Lagos, 127136 ; seasonal variation of larvae, 131 ; Filaria carried by, 133; larvao and pupae killed by raised temperature of water, 135.

Mosquito larrae, search in domestic water-vessels for, 127-136; seasonal variation in water- vessels of. 131; raised temperature of water kills, 135; fish and, 137-139; Girardinus paeciloides preys on, 182 ; green gas-producing plant that kills, 276.

Mosquito pupae, raised temperature of water kills, 135.

Mozambique, distribution of tsetse-flies in, 39-42.

Mucidus africanus, synonym of $M$. mucidus, 246.

" alternans, 246.

"grahami, var. of M. mucidus, 246.

" $\quad$ mucidus, 246, 319, 345.

" scatophagoides, 246.

" sudanensis, synonym of $\boldsymbol{M}$. scatophagoides, 246.

mundulus, Culex, 266, 268.

Musca, 56.

Muscidae, blood-sucking in Gambia, 216,

217 ; in $\mathrm{S}$. Nigeria, 274,275 ; in $\mathrm{N}$.

Nigeria, 321, 328, 346, 347-351.

musculi, Leptopsylla, 269.

Mytilaspis beckii, 88.

" citricola, in Uganda, 88.

Myzomyia, synonym and spp. of, 141, 142 ; type sp. incorrectly cited,.141. of M. rhodesiensis, 268.

" costalis, infected with sporozoits, 6 ; distribution in N. Nigeria, 319-321, 325, $328,330$.

" culicifacies, infected with sporozoits, 6.

" funesta, infected with sporozoits, 6 ; occurrences in $\mathrm{N}$. Nigeria, 320, 321, 337.

" $\quad$ nili, same as $M$. umbrosa, 268.

" rhodesiensis, 268

" rossi, infected with sporozoits, 6 .

" umbrosa, in N. Nigeria, 319, $321,328,345$.

" unicolor, same as $\mathrm{M}$. umbrosa.

Myzorhynchus, sporozoits found in, 7 ; type sp. incorrectly cited, 141.

" barbirostris, 268. 
Myzorhynchus obscurus, may be a var. of M. barbirostris, 268.

" strachani, synonym of $\boldsymbol{M}$. obscurres, 268.

Natal, Culicinae in, 246, 250, 251, 259, 264.

Native names, of blood-sucking insects and other Arthropods, 219, 223, 340 ; of insects and diseases carried by them, 347.

Natives, instruction of, 226.

neavei, Chrysops, 163.

" Culex, 263.

" Hippobosca hirsuta, var., 171.

nebulosa, Culiciomyia, 254-256.

nebulosus, Trichorhynchus, 320, 328.

necopinus, Tabanus, sp. n., 279, 339.

Nematodes, found in Anophelines, 6.

nemorosa, Culicada, 248.

nemorosus, Ochlerotatus, 248.

Neocellia, included in Nyssorhynchus, 141.

Neomelanconion palpale, 226.

$$
\text { " rima, 254, 255, } 256 .
$$

Neostethopheles, synonym of Stethomyia, 141.

neotaéniorhynchus, Culịcelsa, 261.

Nets for Phlebotomus. 55.

Niger River, research along, 315-320.

niger, Taeniorhynchus, 247.

Nigeria, N., haunts of Glossina tachinoides in, 119-126 ; new Anopheles from, 142,143 ; variety of Stegomyia fasciata from, 179 ; Cimex rotundatus in, 180 ; Culex and allied genera in, 244, note, 246, 250, 253, 259, $262,263,264$; research in, 301-356 ; geography of, 303308 ; climate and rainfall, 308$314 ;$ population and triber, $314-315$; records of bloodsucking insects and ticks in, $34,35,345,346$; legislation in, 356 ; subjects requiring further investigation in, 356 .

Nigeria, S., examination of native waterreceptacles in, 127-136 ; fish that prey on mosquito larvae in, 137-139; Anoplura from, 146 ; Mallophaga from, 147, 149,151 ; Cimex rotundatus in, $180 ;$ Culex and allied genera in, 245, 246, 250, 252, 253, 259, 261, 263-265 ; bloodsucking fies in, 109, 273-276.

nigeriensis, Culex, 250.

\# Ochlerotatus, 250.

nigerrima, Mansonia, 254.

nigerrimus, Phlebotomus, 47, 62, 68.

nigra, Chrysoconops, 252.

" Mansonia, 254.

" Mansonioides, 254.

" Stomoxys (see under Stomoxys).

nigrochaetae, Culex, 252, 254-256.

nigrocostalis, Culex, 129-131, 133-263.

nigrofusca, Glossina (soe under Glossina).

nigrothorax, Taeniorhynchus, 252.

nigrum, Lecanium, 92, 100.

" Menopon, sp. n., 151.

nili, Myzomyia, 268.

Nirmus fuscus, from owl, Sudan, 147.

" varius, from raven, S. Nigeria, and starling, Sudan, 147.

„ vulgatus, from owl and starling, Suden, 148.

Niumi Province (Gambia), in regard to tsetses, 211-14, 222 ; vegetation in, 190. nobilis, Holcoceria, 182.

nocturnus, Ochlerotatus, 250.

Nosema?, found in Anophelines, 6.

Notabile (Malta), Phlebotomus found in catroombs at, 48, 51 .

Numida mitrata, Mallophaga parasitic on, $148,150$.

nuttalli, Amblyomma, 320.

Nyasa, Glossina taken in, 19 ; reports of tsetse from, 39, 40; Anoplura from, 145-147 ; new Psyllidae from, 105106 ; no official record of sleeping sickness in N., 181 ; cattle trypanosomiasis in, 181, and note; sleeping sickness in Dowa district, 112 ; babits of blood-sucking flies in, 111-112 ; new Chrysops from, 163 ; Cimex rotundatus in, 180; a Locustid jnjurions to man in, 180 ; Culex and allied genera in, 246, $248,250,259,260,264,265$; new flea from, 269-272.

nyasae, Pseudoeriopsylla, sp. n., 105.

Nycteribiidae, pseudo-joints found in some, 364, note.

Nyssomyzomyia, synonym of Myzomyia, 141. 
Nyssorhynchus, genera included in, 141; t y p e sp. incorrectly cited, 141.

y pharoensis, in Gambia, 201 ; in N. Nigeria, $319,328,345$.

obscurus, Myzorhynchus, 268.

ocellata, Grabhamia, 250.

Ochlerotatus, synonyms of, 246, 247 ; table of spp. of, 247.

,

1)

$\dot{11}$

:

,

11

$n$

,

,

ง)

,

$n$

1)

n

ochraceus, Ochlerotatus, 246, 250.

Taeniorhynchus, 253.

Oculeomyia, included in Culex, 256.

" saravoaki, a var. of Culex ager, 259.

Olfersia aearta, synonym of 0 . intertropica, 172, note.

" dukei, sp. $\mathrm{n}_{\text {., }}$ on a fish-eagle in Uganda, 171.

" (Ornithomyia) intertropica, 172 and note.

ornatothoracis, Culex, 263, 264.

Ornithodorus, instructions for collecting, $23 \%$.
Ornithomyia (see Olfersia).

Oshogbo district (S. Nigeria), bloodsucking flies of, 273-276.

Palaeopsylla gracilis, 259.

" minor, 269.

pallicera, Glossina (see under Glossina), pallidipennis, Haematopota 321, 330, 334. pallidipes, Glossina (see under Glossina). pallidocephala, Culex, 262. pallidostriatus, Culex, 250. pallidothoracis, Culex, 263. pallidum, Menopon, 149. pallipes, Culex, 265.

palpale, Neomelanoconion, 266.

palpalis, Glossina (see under Glossina). " var. wellmani, Glossina, 23.

Pandanus, supposed by natives to poison drinking water, 330 .

Pangonia magrettii, said to be fatal to camels, 176.

Papataci-flies (see under Phlebotomus). papatasii, Phlebotomus (seo under Phlebotomus).

Papio sphinx, predilection of Glossina morsitans for, 206-207, 223 ; potential reservoir of trypanosomes, 223.

par, Culex, 266.

"Tabanus, 207, 321, 324, 326, 346.

parascelos, Culex, 250.

Parasites, control of pests by introduction of, 365-367.

Parinarium mobola, paparium of Glossina morsitans at base of trunk of, 358 .

Parlatoria blanchardi, 88-89, 92.

91."

(Websteriella) zizyphi, in Egypt,

paykulli, Plexippus, 210.

Pecomyia, 250.

Pectinopalpus fuscus, larvae in native water - vessels at Lagos, 129, 130 ; seasonal variation of larvae of, 131 ; usually in foul water. 131 ; associated with Stegomyia fasciata, 132 ; synonym of Culiciomyia nebulosa, 255.

Pediculus capitis, in Sudan, 145.

penetrans, Dermatophilus, 325.

peristictus, Haematopinus, sp. n., 148. 
perniciosus, Phlebotomus (see under (Phlebotomus). persicae, Lecanium, 93.

persicus, Argas, 232.

pertinens, Haematopota, 111.

"Tabanus, sp. n., 286-290, 321, 328, 330, 332-334, 346.

petersi, Enyaliopsis, 180.

pettigrewi, Culex, 250, 262.

Phacochoerus aethiopicus, Anoplura parasitic on, 145.

pharoensis, Nyssorhynchus, 201, 319, 328, 345.

Phlebotominae, 57.

Phlebotomus, of Maltese Is., 47-78; search for breeding places, 48-50 ; habits and occurrence of adults of, $50-52$; seasonal prevalence of, $52-53$; prophylactic measures against, $53-56$; morphology of 57-67; oviposition in captivity, 67 ; synopsis of, 68 ; list of references to, 77-78; description of spp., 6877 ; adults found associated with rabbits, 49.

minutus, apparently rare in Malta, 47 ; described, 6970; much more active than other Maltese spp., 70 ; wing venation of, 62 . nigerrimus, sp. n., 68 ; wing venation, $\mathbf{6 2}$.

papatasii, abundant in Maltese Is., 47 ; breeding places, 48, 49 ; head and appendages of, $57-60$; external genitalia, 61 , 74 ; wing venation, 62 ; male and female described, 73, 74; much more restless in captivity than $P$. perniciososus, 75 ; ovum of, 75 ; larva of, 75, 76 ; pupa of, 76,77; eggs only hatch in moist atmosphere, 75 .

perniciosus, sp. n., abundant in Malta, 47; possible carrier of Papataci fever, 47 ; breeaing places, 49 ; wing venation, 62 ; male and female described, 70 72 ; pupa of, 72-73.
Phoenicoccus, synonym of Sphaerococcus, 104.

Photography of Diptera, 153-160 ; apparatus for, 153, 154; preparation of insects for, 155,156 ; illumination, 156,157 ; magnification, 157,158 : exposure, 158,158 ; development, 159 ; retouching, 159 ; printing, 160.

picae, Menopon, 151.

pilifera, Maillotia, 265.

piliferus, Culex, 265.

pilosellus, Clinocoris, 364, note.

pincerna, Ludlowia, 245, 266.

pipistrelli, Clinocoris, 364, note.

pipiens, Culex, 247, 248, 262, 263.

Piroplasmosis, in dogs in N. Nigeria, 323, 354.

pitchfordi, Anopheles, 143.

Plectropterus gambensis, Mallophaga on, 148, 149, 151.

Plexippus paykulli, preying on Glossina palpalis, 210.

plumosa, Ludlowia, 245.

poeciloides, Girardinus, 182.

poicilipes, Lasioconops, 258.

pollinctor, Stegomyia, 268.

Polyctenidae, 152 ; pseudo-joints found in, 364, note.

Portuguese E. Africa, distribution of Glossina in, 39-42; relation between game and Glossina in, 116-118.

Potamochoerus choeropotamus, Anoplara on, 145.

potis, Chimaeropsylla, g. et sp. n., 269.

pretoriensis, Anopheles, 143.

procerus, Goniocotes, 148.

Prophylactic measures against Phlebotomus, 53-56 ; repellents, 53,54 ; fumigation, 54 ; light, 54 ; artificial air movement, 54 ; traps, 54 ; nets, 55 ; destruction of breeding grounds, 55,56 ; prospodidis, Lecaniodiaspis, 102.

Proteosoma, birds infected with, 7.

Protomelanoconion fuscum, 244.

pruinosus, Culex, 263.

pseudoannulioris, Culex, 258.

pseudocinerea, Culiciomyia nebulosa var., $255,256$.

pseudocinereus, Culex, 254.

pseudoconopas, Chrysoconops, 253.

Pseudoeriopsylla, g.n., 105. 
Pseudoeriopeylla nyasae, sp.n., 105.

Pserdoheptophlebomyia, included in Culex. 256.

madagascariensis, synonym "of Culex quasigelidus, 258. psidii, Pulvinaria, 94.

psusennis, Tabanus, 176, note.

$P$ Pychoda, larvoe in foul water at Lagos, 129, 130, 134.

Prychodidae, 57 ; in Gambia, 218.

Psychodinae, 57.

Psyllidae, n. g. of, 105.

pulcritarsis, Culex, 249.

" Grabhamia, 249.

"Ochlerotatus, 249.

pulcripalpis, Grabhamia, 248, 249.

Palicidae, in Gambia, 218 ; in N. Nigeria, 322, 346.

putlatus, Culex, 264.

pullulus, Tabanus, sp. n., 282.

Pulvinaria jacksoni, in Uganda and W. Africa, 93 ; food plants, 93.

" pridii, injurious to coffee in Uganda, 94.

pumilus, Haplochilus, 182.

punctipes, A poroculex, 258.

punctocostalis, Banksinella, 245.

puniens, Haematopota, 326.

pusillus, Culex, 265.

pygmaeus, Culex, 266.

Pyretophorus, type sp. incorrectly cited, 141.

" costalis, breeding in native domestic water-vessels at Lagos, 133 ; occurrences in water-vessels at Lagos, 130,131 ; found at lowest elevation above sea level, 134 ; breeding in native yards, 136 ; occurrence in Gambia, 205.

quadrilineatus, Ceroplastes, 95-98.

quasigelida, Leucomyia, 258.

quasigelidus, Culex, 258-260, 264.

quasiguiarti, Culex, 264.

quasimodesta, Culicada, 256, 266.

quasiunivittatus, Ochlerotatus, 250.

Radioculex clavipalpus, synonym of Ludlowia chamberlaini, 244, and note.
Railways, recommendations with regard to, 354 .

Rainfall, in Gambia, 191-193; in N. Nigeria, 308-314.

Reedomyia annulata, in N. Nigeria, 320.

, lowisii, 250.

regularis, Diaspis, sp. n., 86, 87.

regulus, Helea (Forcipomyia), 57.

Rest camps, in Gambia, 204, 205, 225 ; in

$N$. Nigeria should be moved further from kurimis, 344, 345.

Khipicephalus falcatus, in N. Nigeria, 330

" sanguineus, on dogs in

Nigeria, 319, 322, 324 ;

biting man, 326.

" simeus, abundant on dogs in

N. Nigeria, 321, 322, 324 ;

on horses in $\mathbf{N}$. Nigeria,

325 ; biting man, 326 ;

found at Baro, 328.

Rhodesia, N.E., new var. of Hippobisca from. 171 ; Cimex rotundatus in, 180.

" N.W., tsetse able to exist without game in, 40.

" S., tsetse found in, 41, 357-361 ; Culicinae in, 249, 250, 259, $262,264$.

Rhus longifolia, 117.

Rhynchocyon cirnei, new flea occurring on, 272.

rima, Culex, 265.

"Neomelanoconion, 254, 255, 265.

rimus, Melanoconion, 265.

Rinderpest and Glossina, 114, 115.

rossi, Anopheles, 141, 143.

rossii, Myzomyia, 6.

rotundatus, Cimex, 179, 180, 212.

Rovama river, fly-belts along, 40, and note; diary of B. T. Barrett's journey down the, 43-46; tsetse abundant along aftuents of, $43,44$.

rubinotus, Culex, 265.

rufinus, Culex, 265.

rusci, Ceroplastes, 97

Saissetia (seo Lecanium).

salicifolii, Agromyza, sp. n., 79.

salisburiensis, Culex, 264.

salsus, Culex, 261.

salus, Culex, 261. 
Swnd-Alies (see Phlebotomus).

sanguineus, Rhipicephalus, 212, 319, 322, 324,326 .

sarawaki, Oculeomyia, 259.

Satcopsyllidae, in N. Nigeria, 325, 346.

Bcale Insects, African, observations on, 85-104.

scapularis, Leucomyia, 247, 256.

" Ochlerotatus, 247.

scataphagoides, Mucidus, 246, 319, 345.

semicinctum, Colpocephalum, 149.

secodens, Tabanus, 182, 202, 320346.

Sona (Mozambique), cattle trypanosomiasis in vicinity of, 41.

Eonegal, French, possibility of diseases being carried from or into, 195.

senegalensis, Haplochilus, 137, note.

sergenti, Culex, 265.

Sierra Leone, outbreak of Yellow Fever in, 127 ; Culicinae in, 246, 259, 263, 265.

silacea, Chrysops, 166, 341-344

simillimus, Cyclops, 129, 130, 134.

simpsoni, Culex, 263.

Simulium, in N. Nigeria, 317, 319, 324, 326.

simus, Rhipicephalus, 321, 322 324-326, 328.

sinensis, Culex ager, var., 259.

„Leucomyia, 259.

$$
\text { " } " \quad \text { gelida, var., } 259 .
$$

Siphonaptera, new, from Nyasa, 269-272 ; in N. Nigeria, 322, 325, 346.

sjoestedti, Colpocephalum, 149.

Sleeping Sickness, nccurrence in Doxa district, Nyasa, 112 ; in Gambia, 187, note, 188, 205, 210, 214, 223 ; camps for, $224,353,355$; method of minimizing spread of, 225 ; not in Llesha and and Oshogbo distriots, S. Nigeria, 276 ; colour convention for, 297, 298 ; occurrence in N. Nigeria, 331-333, 337-339, $344,352,353$; native names for, 347 ; no case discovered in villages on Garara River, 352 ; sporadic in Baro, 352, 353 ; natives of $W$. Africa though immune may act as reservoirs of, 353 .

socialis, Tabanus, 208, 209.

somaliensis, Culex, 261.

Somaliland, British, occurrence of Stegomyia fasciata in, 179 ; new Tabanus in, 176 ; Culex in, 261.

spathipalpis, Theobaldia, 251.
Sphaerocaccus draperi, synonym of $S$. marlatti, 104.

marlatti, common in Lower Egypt, 104 ; remedy for, 104.

sphinx, Papio, 206, 207, 223.

Spilopsyllus cuniculi, 269.

spinosum, Menopon, 149.

spirocarpoides, Acacia, 116.

Sporozoa, found in Anophelines, 6.

Sporozoits in mosquitos, methods for detecting, 1-8.

Steamers and Launches, tsetse invading, $190,198,202,204,205,207-210$; effective mosquito proofing for, 226 ; mosquitos breed in "bilge water" on, 354.

Stegomyia africana, bites only at dusk, 275.

fasciata, identification of larva of, 127 ; distribution of larra at Lagos, 131,135 ; number of vessels in which were found larvae of, 130 ; seasonal variation of larvae of, 131 ; occurs in Sudan, 179 ; may transmit virus of horsesickness, 179 ; vector of dengue fever, 179 ; abundant in coast towns of British Somaliland, 179 ; variations of, 179 ; in Gambia, 188, 195 ; pale var. common in Algeria, 248; in N. Nigeria, 318, 319, 328, $351,354,355$.

" longipalpis, 268.

" pollinctor, synonym of S. longipalpis, 268.

stenopygus, Akidoproctus, 148.

Stethomyia, considered distinct, 141; Neostethopheles, synonym of, 141.

Stomoxys, cattle trypanosomiasis spread by, 41 ; as a protozoal carrier, 223 ; inoculation experiments should be carried out with, 323.

" calcitrans, empty pupas of in caves of Notabile, Malta, 48 ; in Gambia, 197, 207, 208 ; in N. Nigeria, 319-321, 323, 324, $327,333,346$.

nigra, in Gambia, 201, 202, 207, 208 ; common in Oshogbo, S. Nigeria, 275 ; in N. Nigeria, 317, 319-321, 323, 324, 327, 346. 
strachani, Myzorhynchus, 268.

subangustuss, Tabanus, 275, 320, 325-328, 346.

submorsitans, Glossina (8ee under Glos$\sin a)$.

substriata, Chionaspis, 90.

subtilis, Grabhamia, 248.

Budan, Onlicinae in, 245, 246, 250, 252$254,259,262,263,265$.

sudanensis, Mucidus, 246.

suis, Haematopinus, 145.

sycophanta, Calosoma, 369.

Tabanidar, cattle trypanosomiasis spread by, 41; three new spp. of, 161-168; two new spp. from Sudan, 173-177 ; Bembex preying on, 182 ; list of apeciea in Gambia, 215-216 ; in $\mathrm{S}$. Nigeria, 274, 275 ; new African species, $279-290$; abundant at Zungern, $\mathbf{N}$. Nigeris, 323 ; spp. occorring in $N$. Nigeria, 321, 328, 339, 346 ; none soon along River Garara, 337 ; native names of, 347.

tabaniformis, Glossina, 9, and note, 108.

Tabanus africanus, habits and habitats, 112, 346.

albipalpus, in Gambia, 215 ; in N. Nigeria, $325,327,346$.

biguttatus, habits, 112.

" var. croceus, in $N$ Nigeria, 321, 324, 325, 328, $330,346$.

camelarius, sp. N., 173 ; attacking camels, 175.

claritibialis, 282.

copemani, sp. n., 281.

crocodilinus, sp. n., 284.

ditaeniatus, habitats of, 111 ; in Gambis, 200, 207; in N. Nigeris, 321, 324, 346 .

fasciatus, in Gambia, 202 ; in $\mathbf{N}$. Nigeria, 320, 346.

gratus, in N. Nigeria, 321, 330, 334, 346.

irroratus, 286.

latipes, in N. Nigeris, 318, 321, 328, 346.

laverani, in Gambia, 202 ; in $\mathrm{N}$. Nigeria, 346.

leucostomus, 176, note, 177.

maculatissimus, 286.
Tabanus mordax, sp. n., 175 ; said to be fatal to camels, 176.

necopinus, sp. n., $279,339$.

par, in Gambia, 207 ; in Nigeria, $321,324,326,346$.

pertinens, sp. n., 286 ; distribution, 289-290 ; troublesome to human beings, 290 ; in $\mathrm{N}$. Nigeria, 321, 328, 330, 332$334,346$.

"psusennis, synonym of leucostomus, 176 , note.

pullulus, sp. $\dot{\text {., }} 282$; distribution, 283-284.

secedens, preyed upon by Bembex, 182 ; posible vector of Trypanosoma pecorum, 182 ; in Gambia, 202 ; in N. Nigeria, 320, 346.

socialis, in Gambia, 208, 209.

subangustus, habits in $\mathrm{S}$. Nigeria, 275 ; in $N$. Nigeria, 320, 325-328, 346.

sujis, 290.

taeniola, in N: Nigeria, 318, 320, $321,324,327,328,330,339$, 346.

taeniola, var, variatus, habits and habitats, 111, 112 ; in Gambia, 200-202 204-207, 216.

thoracinus, in S. Nigeria, 275 ; in N. Nigeria, 321, 346.

unitaeniatus, habits, 111 ; males common, 112.

Tachardia actinella, in Natid, 100.

, albida, in Natal, 100.

" decorella, new to Africa, 85, 100 ; on Anona murricata, 100.

" longisetosa, sp. n., 102 ; infested with Chalcidids, 103 ; on Ficus, 103.

Tachinidae, parasites on larvae of Gipsy Moth, 369, 370.

tachinoides; Glossina (see under Glossina). taeniarostris, Banlesinella, 245.

taeniavostris, Grabhamia, 259.

taeniola, Tabanus (soe under Tabanus).

taeniopygus, Fundulus, 182.

taeniorhynchoides, Culex, 258.

Taeniorhynchus, characters of, 251-252; tables of spp. of, $25 \mathbf{9}$; Manoonia a ojnoryin. of 262 . 
Taeniorhynchus africanus, not a true Taeniorhynchus, 266.

$1 \%$

")

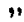

,

,

” lateralis, 245.

; metallicus, 252.

" niger, included in Ochlero. tatus, 247.

nigrithorax, 252.

ochraceus, 253.

taeniorhynchus, 251.

tenax, included in Culex, 256.

tenax, var. maculipes, synonym of Culex quasigelidus, 258.

titillans, type of genus, 251, 252.

violaceus, synonym of T. metallicus, 252.

taeniorhynchus, Chrysoconops, 252.

" Culicelsa, 247, 249.

" Taeniorhynchus, 251.

Taphozous hildegardeae, 364 .

tenax, Taeniorhynchus, 256, 259.

Tendaba (Gambia), blood-sucking flies abundant at, 207-208; clearing needed at, 225.

tenuicrus, Haematopota, 321.

tenuivalvatum, Lecanium, sp. n., 92-93.

Tete district (Mozambique), fly areas in, 41.

thalassius, Culex, 260, 261.

theileri, Culex, 260, 262.

Theobaldia annulata, 251.

" spathipalpis, 251.

thoracinus, Tabanus, 275, 321, 346.

Thysanoptera, 238.

tibialis, Linognathus, 147.

igripes, Culex, 251, 261, 321. tigripes, var. consimilis, Culex, $2 \overline{5} 9$.

" var. fusca, Culesc (seo under Culex).

titillans, Culex, 252

"Taeniorhynchus, 251, 252.

Transvaal, relation between game and tsetse in, 114-116 ; Culex and alliod genera in, 248, 249, 251, 254, 259--264.

Traps for Phlebotomus, 54.

tremae, Lecanium, 93.

Trematodes, found in Anophelines, 6.

Trichochetes climax, from goats, $\mathbf{S}$. Nigeria, 147.

Trichoprosoponinae, 241.

Trichorhynchus (Culiciomyia) nebralosus, in N. Nigeria, 320, 328.

trilobitiformis, Aspidiotus, 85.

Trinoton luridum, from spurwing goose, Sudan, 151.

Trypanosoma brucei, found in blood of horses in N. Nigeria, 353 ; more virulent than $T$. rivax, 353.

" gambiense, natives of Gambia infected witb, 188 ; $5 \cdot 4$ per cent of population of Essan infected with, 213.

"vivax, found in blood of horses in N. Nigeria, 353.

Trypanosomes, investigation of, in wild animals, 170 ; in bulls, 181 ; blood of baboons potential reservoir of, 223 ; not certain that horses and cattle are infected with the same, 213 ; found in horses, 353.

Trypanosomiasis of Cattle, spread by Stomoxys or Tabanidae, 41 ; Glossina morsitans in relation to, 181 , note; $G$. breripalpis in relation to 181,182 ; cases in district between Karonga and Songwe rivers, Nyasa, 181 , note ; in Gambia, $188,200,212,214,223,226$; investigation required into forms of, 356 ; prevalent in N. Nigeria, 353.

Trypanosomiasis of Horses, in N. Nigeria, $319,320,323,330,332,334,336,338$ 342,344 ; not always carried from horse to horse, 345,353 ; and of dogs, 344 ; camps for, 226, 320, 323, 332.

Tsetse-flies (see Glossina),

Uganda, Glossina taken in, 26, 27 ; new mosquito from Entebbe, 38 ; Coccidae from, $85,86,87,88,90,92-100,103$ 
Culex and allied genera in, 245, 248, 250, 252, 253, 256, 259, 263-265 ; Chrysops centurionis, n. sp. from, 164; Hip. pobosca hirsuta, n. sp. from, 169 . Olfersia dukei, n. sp. from, 171 ; fish preying on mosquito larvae in, 182 ; Bembex preying on Tabanidae in, 182. ugandae, Ceroplastes, 94, 96.

umbrosa, Anopheles, 142.

" Myzomyia, 268, 319, 321, 328, 345.

unicolor, Myzomyia, 268.

uniformis, Culiciomyia, 255.

" Mansonia, 253.

" Mansonioides, 253.

unitacniatus, Tabanus, 111, 112.

univitiatus, Culex, 250, 260, 262, 345.

Uranotenninae, 218, 241.

Valetta, searched for breeding places of Phlebotomus, 48, 49; Phlebotomus, in cellars and prison cells of, 51 .

variegatum, Amblyomma, 197, 319, 325, 330.

varius, Nirmus, 147.

versicolor, Hippocentrum, 275, 319, 320, 324, 325, 327, 330, 346.

vigilax, Culex, 263.

" Ochlerotatus, 250.

Vinsomia, 97.

phissonioides, Ceroplastes, sp. n., 96.

violaceus, Taeniorhynchus, 252.

viridis, Culex, 263.

vittata, Baematopota, 111.

vituli, Linognathus, 146.

vivax, Trypanosoma, 353.

vocifer, Haliaëtus, 172.

vulgatus, Nirmeus, 148.
Waterbuck, in relation to Glossina morsitans, 43-46; Hippobosca infesting, 169-172.

Water supply, danger of wells for, 197, $205,206,331,333$; Glossina palpalis swarming in $N$. Nigeria near, 343 ; clearing to be done round wells and springs, 344.

watsoni, Anopheles, 143, 330.

Websteriella (see Parlatoria).

wellmani, Glossina palpalis, var., $2 \mathbf{3}$.

wellmanii, Chrysops, 167, 168.

Wells, danger of, 197, 205, 206, 331, 333 .

zoilcocksii, Grabhamia, 248.

Yellow fever, outbreak in Sierra Leone and Gold Coast, 127 ; in Bathurst, Gambia, 188, 195, 224; not reported from N. Nigeria, 351 .

Zambesi river, fly areas of, 41.

Zambesia district, considerable fly belts in, 40.

zeltneri, Culex, 266.

zizyphi, Parlatoria, 91.

zombaensis, Culex, 264.

Zangera (N. Nigeria), importance of, 304 ; biting insects and ticks in, 321, 322 ; tsetses nearly always present in, 322 ; clearing required near, 322 ; try. panosomiasis common amongst horses in, 323 ; piroplasmosis in dogs in, 323, 354 ; game near, 323 ; trypanosomes found in pony at, 324 ; recommendations with regard to, 355 .

Zygotes in mosquitos, methods for detecting, 1-8. 


\section{INDEX TO NAMES OF PERSONS.}

Aders, Dr. W. M., 373.

Alcock, Lieut.-Col. A., 141, 241.

Anderson, T. J., 373.

Annandale, N., 59, 61.

Ansorge, Dr. W. G., 255.

Archibald; Capt., 179.

Archibald, Dr. J.'W., 184, 321.

Arribalzaga, 252.

Ashworth, Dr. J. H., 289.

Austen, E. E., 9, note, 10, note, 14, nate, 31, $40,41,107,122,161-177,181,249$, 279-290, 298, 339, 357.

Babbington, Capt., 77.

Bagshawe, Dr. A. G., 298.

Balfour, Dr. Andrew, 179.

Barclay, Dr. A. H., 277, 283.

Barnshaw, A. L., 183.

Barrett, H. T., 40, note, 43-46, 184.

Beaman, Capt., 77.

Bell, Sir Hesketh, 356.

Beresford, M: H. de la P., 356.

Beśt, Dr., 215.

Bevan, L. E. W., 41, note.

Birt, Lieut. Col. C., 49.

Bissell, Capt. F. E., 350, 353.

Blair, Capt. A. H., 273, 274, 277.

Blair, Dr. M. Oameron, 341, 356.

Blakeney, Major, 338.

Bödeker, Dr. H. A., 277, 373.

Boulenger, G. A., 137, note, 139.

Boyce, Sir Rubert, 351.

Brown, Henry, 81.

Bruce, Col. Sir David, 27, 31, note, 170.

Budgen, T. A., 81.

Burdett, Dr., 217.

Campbell-Irons, A., 81.

Carand, C. A., 81.

Carlyle, T. F., 81.

Carpenter, Dr. G. D. H., 278.
Carter, H. F., 2, note, 37-38.

Champion, A. M., 373.

Chartres, Dr. E. A., 319, 354, 373.

Cherrett, Dr. B. W., 373.

Chisholm, James A., 183.

Christophers, Dr., 5, 6, 7.

Clark, Dr. W. S., 82.

Cockerell, T. D. A., 100, 102, 104.

Cody, W. S., 277.

Collett, Dr., 184.

Collin, James E., 79, 80.

Connal, Dr. A. 184, 277.

Copeman, E. A., 282, 284.

Copland, Dr. J. G., 184.

Corsellis, M. H., 81.

Cox, Rev. H. A. M., 81.

Crawford, Major G. S., 53, 77.

Currie, Dr. J., 373.

Dalziel, Dr. J. M., 262, 289, 347, 350 .

Davey, Dr. J. B., 19, 180, 181, 145, 146, $283,285$.

David, B., 82.

Dayrell, E., 184.

Denton, Sir George, 209, 226.

Dibblee, Major F. I., 70, 77.

Dibblee, Mrs., 77.

Dickie, James, 81.

Drake-Brockman, Dr. R. E., 82, 176, 179, 277.

Dudgeon, G. C., 217.

Duke, Dr. H. L., 172, 373.

Duncan, N. O., 81.

Dutton, Dr. J. E., 18, 187, 188, 195, 215, 216, 217, 218.

Dyar, H. G., 141, 246, 247, 251, 252, 253.

Eaton, Rev. A. E., 248.

Edwarde, F. W., 141-143, 215, 241-268.

Edwards, William, 81. 
Falk, G., 81.

Farquhar, J. H. J., 82, 109, 277.

Fatteh ud Din, Dr., 184.

Fell, T. E., 373.

Fisher, Dr. Walter, 81.

Finte, W. F., 365.

Foragth, H., 183.

Foster, A. N., 215-217, 277.

Foulkes, Capt. H. D., 81

Foy, Dr. H. A., 280, 339.

Franklin, Dr. J. C., 217.

Fraser, Capt. A. D., 161, 165, 184, 245.

Fraser, Donald, 81.

Fülleborn, Dr., 100.

Gallagher, Dr. G. H., 184.

Gaye, J. A. de, 82, 277.

Gouldsberg, Henry C., 183.

Gowdey, C. C., 82, 85-104, 182, 184, 277, 373.

Grabam, Dr. W. M., 82, 127-136, 137$139,153-160,255,273$.

Grassi, Prof. B., 49, 56-61, 66.

Gray, Dr. G. M., 82.

Gray, Dr. R. W., 180, 184.

Greaves, J. A. Ley, 82, 184, 373.

Green, E. E., 85, 93, 97.

Grünberg, Dr. K., 268.

Gusb, Dr. Howard W., 81.

Haddon, E. B., 183.

Hailstone, Dr., 184.

Hamilton, Major J. S., 39, 40, 113-118.

Hannington, Dr., 109.

Harrington, Hubert T., 183.

Hearsey, Dr. H., 180.

Henderson, Dr. F. L., 373.

Hiscock, Dr. R. C., 184, 320.

Hood, Dr. T., 197, 215-217, 224, 226.

Hopkinson, Dr. E., 215-217.

Howard, C. W., 39-42, 117.

Howard, Dr. L. O., 365.

Hughes, F., 102, 104.

Humfrey, Capt. L. E. H., 82, 273, 274, 276.

Hutchins, E., 184, 373.

Hynde, R. A., 81.
Ingram, Dr. A., 35, 82, 328, 352.

Inness, Dr. W. D., 326, 373.

Jack, Rupert W., 357-361.

Jackson, F. J., 277, 284, 364.

James, Capt., 141.

Jemmett, C. W., 184.

Kellogg, Prof. V. L., 145-152.

Kilroy, Surg. Lancelot, 77.

King, Harold $H ., 82,97,145,147-152$, 173, 175, 176, \& note, 179, 285, 289.

Kinghorn, Dr. Allan, 18, 34, 107, 109, 291-295.

Kleine, Dr. 292.

Knab, Dr. F., 141, 251-253.

Lamborn, W. A., 184, 277.

Lane, Capt G., 183.

Leal, Dr. Amaral, 40.

Lefroy, H. Maxwell, 371.

Lloyd-Jones, Capt., 77.

Lloyd, Ll., 295.

Lounsbury, C. P., 371.

Luhn, Dr. O. S. F., 185.

McCloy, Surg. A., 110.

McConnell, Dr. Robt. E., 373.

Macdonald, Dr. P. H , 277, 373.

Macfarlane, Dr. A. M., 77.

Macfie, Dr. J. W. S., 35, 82, 277, 289, $328,335,352,356,374$.

McKay, Dr. F. W., 34, 185.

Mackay, Rev. J., 276.

Mackie, Capt. F. P., 27, 170.

McKinney, Dr. 325.

McLeay, Dr. C. W., 350.

Manning, G. F., 81.

Manuk, Capt. M. W., 319.

Marett, Capt. P. J., 47-49, 51, 55, 68, 77.

Marshall, Guy A. K., 107, 142, 145, 241, 248, 298.

Marshall, Dr. C. H., 185.

Marshall, Hugh O., 183.

Maskell, W. M., 102, 104.

Maugham, R. O. F., 117

Mayer, Dr. T. F. G., $82,142,185,255$, 273-276, 277. 
Moffat, Rev. M., 183.

Moiser, Dr. B., 83, 119-126.

Morrison, Dr. W., 35, 36, 83, 323, 324, $328,329,330,352$.

Monat, Dr. A., 374.

Murphy, Dr. J. C., 280, 374.

Murray, L., 81.

Murray, Dr. Wm. Ansley, 81.

Nair, T. D., 374.

Neave, S. A., 83, 85-104, 106, 162, 166, note, 180-182, 185, 284, 289, 374.

Newstead, Prof. R., 9-36, 47-78, 85-104, 105-110, 203, 259, 348.

O'Brien, Col. C. W., 226.

Old, Dr. J. E. S., $81,83,185,278,282$, 374.

Owen, Dr. H. B., 180, 185.

Paine, J. H., 145-152.

Pask, Dr. E. H. Allon, 81, 83, 147.

Patterson, W. H., 278, \& note.

Percival Bey, El-Kaimakam, 179.

Percival, J., 81.

Perkins, Dr. R. C. L., 370.

Piaget, A., 148.

Pirie, Dr. G. J., 185, 344.

Powell, W. A., 183.

Prentice, George, 81.

Prichard, Dr. W. Owen, 374.

Pugh, Dr. J., 374.

Putron, P. de, 317, 326.

Rendle, Dr. A. C., 185, 374.

Ross, H. Malcolm, 374.

Rothschild, Hon. N. Ch urles, 269-272, 363-364.

Roubaud, E., 292, note.

Roupell, Hon. E. C., 72, 77.

Rundle, Gen. Sir Leslie, 77.

Sanderson, Dr. Meredith, 83, 111, 112, 181, 278.

Sant' Anna, Dr., 40, 41.

Schalkwijk, Rev. J. van, 183.

Schaudinn, Dr., 8.

Scholefield, S. W. J., 374.
Scicluna, Hon. C. Carnana, 77.

Sergent, E., 7.

Shircore, Dr. J. O , 26, 27, \& note.

Silberrad, H., 374.

Simpson, C. B., 278.

Simpson, Jas. J., 83, 122, 146, 147, 149, $151,179,180.185,187-239,278,289$, 290, 297-299, 301-356, 374.

Sjöstedt, Prof. Y., 251, 253.

Smythe, Dr. A. W., 185.

Someren, Dr. R. A. L. van, $149,170,171$, $186,278,374$.

Speiser, Dr. P., 57, 251, 253.

Stannus, Dr. Hugh S., 81, 163, 180, 181, note, 185, 272, 278.

Stephens, Dr. J. W. W., 1-8, 355.

Steward, Capt., 77.

Strathairn, Dr. G. C., 278.

Stuhlmann, Dr. F., 181.

Surcouf, B., 286.

Swann, Dr. A. J. T., 81.

Swynnerton, C. F M., 374.

Taschenberg: 148.

Theobald, F. V., 141, 143, 185, 246-251, $253,255,259,260-263,268$.

Thompstone, Dr. S. W., 302, 330, 356.

Thornicroft, H., 183.

Todd, Dr. J. L., 18, 187, 188, 213, 224.

Traill, Capt. H. L. Norton, 81.

Turnbull, A. M. D., 180, 278.

Ventrillon, Dr., 258.

Vosseler, Prof., 100.

Watson, Dr. C. E. S., 83, 186, 289.

Wesché, W., 10, note.

Wheelwright, 276.

Wiggins, Dr. C. A., 27, 38, 180. 186.

Willcocks, F. C., 80, 83, 85-104.

Wolbach, Dr., 188, 213.

Woosnam, R. P., 374.

Young, R. A., 183.

Zammitt, Prof. T., 77.

Zimmermano, Prof. A., 93. 


\section{INDEX TO PLANTS ATTACKED BY INSECTS.}

Acacia, 97, 100.

Acacia arabica, 102, 104.

Albizzia, 92.

Alternanthera versicolor, 94 .

Amakebe, 94.

'Anona muricata, 97, 98, 100.

Antigonon octopus, 86.

Apricot, 92.

Baikea eminii, 97.

Bark-cloth treo, 98, 100, 103.

Oacao, 93.

Cassia floribunda, 90.

Oitronella gesse, 93.

Citrue, 88, 91.

Coffee, 94, 97.

Cotton, 93.

Crataegus, 97.

Date palm, 104.

Datura alba, 86.
Ficus, 92, 93, 97, 100, 102, 103.

Justicia alba, 88.

Magnolia, 86.

Mango trees, 86, 100.

Marlehamia platycalyx, 97.

Mish-Mish, 92.

Nsambyia, 93.

Oleander, 85.

Opuntia, 87.

Orange, 91.

Palm, 90.

Phoenix, 104.

Poplar, 91.

Prickly Pear, 87.

Psidium guyava, 98

Sunt, 104.

Vine, 100 


\section{ERRATA.}

P. 68, lines 9 and 12, transpose the characters of the claspers of tho male given for $P$ hlebotomus perniciosus and $P$. papatasii.

P. 73 (in synonymy of Phlobotomus papatasii), for "Hermasson minutus" read "Haemaseson minutus."

P. 145, for "Podiculis capitis" read "Pediculus capitie"

P. 148, for "Comiocotes givas" read "Goniocotes gigan."

P. 149, for "Liporus baculus" and "Liperus gambensis" roed "Lipewrus baculus and "Lipeurus gambensie" respectively.

P. 214, line 25, for "protozooal" "protozoal."

P. 215, table, for "Chrysops longicornis, F.," read "Chrysops longicornis, Macq."

P. 248, under O. nemorosus, for "Rev. E. A. Eaton" read "Rov. A. E. Eaton."

P. 345, table of Culicina, for "Mucidus mucidus, Theo.," "Stegomyia fasciata, Theo.," and "Stegomyia sugens, Theo.", read" "Mucidus mucidus. "Kursch," "Stegomyia fasciata, 1.," and "Stegomyia sugens, Wiod.," rospectively. P. 346, table of Tabanidae, for "Haematopota cordigera, Anst." and "Tabanus pluto,
Wied.," read " Haematopota cordigera, Big.," and "Tabanus pluto, Walk.," respectively.

P. 346, table of Siphonaptera, for "Ctenocephalus canis, Dugde," read "Ctenocephalus canis, Cartis."

P. 363, title, for "Uganda" read "British East Africa."

LONDON :

PRINTED FOR HIS MAJESTY'S STATIONERT OFFICE, By DARLING \& BON, Ltd., 34-40, BAcon Strmet, E.

1912. 